\title{
PENDEKATAN PRINCIPAL COMPONENT ANALYSIS PADA DATA DEMAM BERDARAH DENGUE DI PROVINSI MALUKU UTARA
}

\section{Principal Component Analysis Approach on Data Dengue Hemorrhagic Fever in North Maluku Province}

\author{
Seba Ririhena*1, Samsul Bahri Loklomin² \\ ${ }^{1,2}$ Program Studi Matematika Fakultas Ilmu Alam dan Teknologi Rekayasa, Universitas Halmahera \\ Jln. Wari Ino Tobelo, Maluku Utara- Indonesia \\ e-mail:1*ebaririhena@gmail.com ; 2 samsul.bahriloklomin@gmail.com \\ Corresponding author *
}

\begin{abstract}
Abstrak
Provinsi Maluku Utara termasuk Provinsi dengan banyak kasus penderita Demam Berdarah Dengue (DBD) di Indonesia Timur. Berbagai faktor penyebab meningkatnya DBD seperti lingkungan, kebersihan diri dan prasarana kesehatan yang belum memadai di Provinsi Maluku Utara. Tujuan dalam penelitian ini adalah pengelompokkan multivariabel terjadinya kasus DBD menjadi beberapa komponen yang lebih sederhana dengan metode Principal Component Analysis (PCA). Metode PCA adalah suatu teknik statistik untuk mereduksi variabel yang berjumlah banyak menjadi lebih sederhana. Hasil penelitian diperoleh 1 variabel yang tidak memenuhi nilai KMO sehingga variabel tersebut dieleminasi. Keseluruhan variabel setelah salah satu variabel dieliminasi diuji memenuhi nilai KMO dan MSA. Semua prediktor dalam penelitian ini membentuk 1 komponen variabel prediktor yang digunakan adalah variabel penduduk bukan angkatan kerja $\left(\mathrm{X}_{1}\right)$, tenaga medis $\left(\mathrm{X}_{2}\right)$, penduduk usia rentan $\left(\mathrm{X}_{3}\right)$, penduduk angkatan kerja $\left(\mathrm{X}_{4}\right)$, desa dengan sarana kesehatan $\left(\mathrm{X}_{5}\right)$, fasilitas kesehatan $\left(\mathrm{X}_{6}\right)$.
\end{abstract}

Kata Kunci : Provinsi Maluku Utara, Demam Berdarah Dengue, Principal Component Analysis.

\begin{abstract}
North Maluku Province is one of the provinces with many cases of Dengue Hemorrhagic Fever (DHF) in Eastern Indonesia. Various factors cause the increase of DHF such as environment, personal hygiene and inadequate health infrastructure in North Maluku Province The purpose of this research is to group the multivariable of dengue cases into several simpler components using the Principal Component Analysis (PCA) method. The PCA method is a statistical technique for reducing a large number of variables to become simpler. The results showed that 1 variable did not meet the KMO value so that the variable was eliminated. All variables after eliminating one of the variables are tested to meet the KMO and MSA values. All predictors in this study form 1 predictor component variable used are non-labor force population (X1), medical personnel (X2), vulnerable age population (X3), workforce population (X4), villages with health facilities (X5), health facility (X6).
\end{abstract}

Kata Kunci : North Maluku Province, Dengue Hemorrhagic Fever, Principal Component Analysis 


\section{PENDAHULUAN}

Salah satu penyakit menular yang masih menjadi masalah kesehatan masyarakat di Indonesia terkhususnya di Maluku Utara adalah Demam Berdarah Dengue (DBD). DBD adalah penyakit yang disebabkan oleh virus famili Flaviridae yang ditularkan oleh nyamuk (arthropod borne virus $=$ arbovirus) yaitu Aedes aegypti sebagai vektor utama dan Aedes albopictus sebagai vektor sekunder [1]. Kasus DBD di Maluku Utara terus mengalami peningkatan. Pada bulan januari 2019 terdapat 152 kasus dan pada bulan juli meningkat menjadi 707 kasus [2]. Peningkatan ini disebabkan oleh berbagai faktor, yang paling dominan adalah faktor iklim dan faktor kesadaran masyarakat. Perubahan perilaku nyamuk Aedes aegypti penyebar virus DBD yang biasanya hanya menggigit manusia pada pagi dan sore hari sesuai hasil penelitian kini menggigit pula pada malam hari [3]. DBD merupakan penyakit yang sangat berbahaya, oleh karena itu penting bagi masyarakat untuk mengetahui faktor-faktor penyebabnya. Untuk mengetahui faktor-faktor penyebab DBD khususnya di Provinsi Maluku Utara dapat digunakan berbagai metode dalam statistika diantaranya analisis regresi, korelasi, spline maupun analisis faktor.

Salah satu analisis atau metode yang dapat digunakan dalam melihat tingkat hubungan antara variabel penelitian adalah analisis faktor. Analisis Faktor adalah sebuah teknik yang digunakan menjelaskan hubungan atau korelasi antara berbagai indikator independen yang diobservasi. Prinsip dasar dalam analisis faktor adalah menyederhanakan deskripsi tentang data dengan mengurangi jumlah variabel/dimensi [4]. Principal Component Analysis (PCA) adalah salah satu metode dalam analisis faktor dimana beberapa faktor yang akan terbentuk berupa variabel laten yang belum ditentukan sebelum dianalisis dan bersifat acak. Tujuan penelitian ini adalah untuk membentuk komponen atau faktor dari keseluruhan variabel penelitian dan keterkaitan antara DBD serta melihat secara statistik hubungan faktor-faktor penyebab DBD di Provinsi Maluku Utara. Data pada penelitian ini dibatasi pada data Cross Section dan sumber data dari Publikasi Dinas Kesehatan Provinsi Maluku Utara.

\section{METODE PENELITIAN}

\subsection{Analisis Faktor}

Analisis faktor adalah teknik analisis untuk menggambarkan hubungan keragaman data beberapa variabel dalam sejumlah kecil faktor. Variabel-variabel yang mempunyai korelasi tinggi akan dikelompokkan dalam satu faktor. Sebelum dilakukan analisis faktor penting dilakukan uji kecukupan data dengan menggunakan Kaiser Mayer Olkin (KMO) dengan menggunakan hipotesis berikut.

$\mathrm{H}_{0}$ : Jumlah data cukup untuk dilakukan analisis faktor

$\mathrm{H}_{1}$ : Jumlah data tidak cukup untuk dilakukan analisis faktor.

Daerah penolakannya adalah jika nilai $K M O \leq 0,5$ maka tolak $H_{0}$. Jika diperoleh nilai KMO>0,5 maka dapat diputuskan gagal tolak $H_{0}$. Dalam penyelesaian analisis faktor, langkah-langkah yang dilakukan adalah:

1. Menghitung korelasi semua variabel

Uji Bartlett digunakan untuk menguji persamaan korelasi antara dua atau lebih data independen. Hipotesis pada pengujian ini adalah:

$H_{0}: \rho=I$ (Matriks korelasi sama dengan matriks identitas)

$H_{1}: \rho \neq I$ (Matriks korelasi tidak sama dengan matriks identitas)

Statistik uji yang digunakan adalah sebagai berikut.

$$
T=\frac{n-1}{(1-\bar{r})^{2}}\left(\sum \sum_{i \neq k}\left(r_{i k}-\bar{r}\right)^{2}-\hat{\gamma} \sum_{k=1}^{p}\left(\overline{r_{k}}-\bar{r}\right)^{2}\right)
$$

dengan

$$
\overline{r_{k}}=\frac{1}{\mathrm{p}-1} \sum_{i=1}^{\mathrm{p}} r_{i k}, k=1,2, \ldots, \mathrm{p}
$$

2. Estimasi Faktor Loading

Estimasi faktor loading menggunakan dasar analisis komponen utama. Matriks taksiran dari loading faktor yang diberikan komponen utama adalah:

$$
\hat{L}=\left[\sqrt{\lambda_{1} e_{1}}: \sqrt{\lambda_{2} e_{2}} \vdots \ldots \vdots \sqrt{\lambda_{m} e_{m}}\right]
$$




\section{Rotasi Faktor Loading}

Transformasi pada faktor loading dengan menggunakan metode tegak lurus Varimax (Varimax Orthogonal Rotation), yang menghasilkan loading faktor baru $\mathbf{L}^{*}$. Rotasi, yang menghasilkan faktor loading baru $\mathbf{L}^{*}$.

$$
\mathbf{L}_{(\mathbf{p} \times \mathbf{m})}^{*}=\mathbf{L}_{(\mathbf{p} \times \mathbf{m})} \mathbf{T}_{(\mathbf{m} \times \mathbf{m})}
$$

dimana $\boldsymbol{T}$ adalah matriks transformasi yang dipilih sehingga didapat $\boldsymbol{T T}^{\prime}=\boldsymbol{T}^{\prime} \boldsymbol{T}=\boldsymbol{I}$. Setelah dilakukan rotasi, selanjutnya mencari nilai masing-masing faktor $F_{1}, F_{2}, \ldots, F_{m}[6]$.

\subsection{Principal Component Analysis}

Principal Component Analysis merupakan salah satu metode analisis multivariat yang digunakan untuk mereduksi dimensi data dalam struktur dimensi data yang lebih sederhana. Analisis komponen utama secara aljabar merupakan kombinasi linier tertentu dari p variabel random $\boldsymbol{X}_{\boldsymbol{l}}, \boldsymbol{X}_{2}, \ldots, \boldsymbol{X}_{\boldsymbol{P}}$. Secara geometris kombinasi linier ini menyatakan seleksi suatu koordinat baru dengan memutar sistem koordinat semula dengan $\boldsymbol{X}_{\boldsymbol{l}}, \boldsymbol{X}_{2}, \ldots, \boldsymbol{X}_{\boldsymbol{P}}$ sebagai sumbu koordinat. Jika vektor random $X=\left[X_{1}, X_{2}, \ldots, X_{P}\right]$ berdistribusi multivariate normal dengan vektor mean $\mu=\left[\mu_{1}, \mu_{2}, \ldots, \mu_{p}\right]$ dan matriks varian kovarian $\Sigma$ dengan pasangan eigenvalue dan eigenvector adalah $\lambda_{1} \geq \lambda_{2} \geq \cdots . \lambda_{p}>0$. Maka kombinasi linier komponen utama adalah sebagai berikut:

$$
\begin{aligned}
& Y_{1}=e_{1}{ }^{\prime} X=e_{11} X_{1}+e_{21} X_{2}+\cdots+e_{p 1} X_{p} \\
& Y_{2}=e_{2}{ }^{\prime} X=e_{12} X_{1}+e_{22} X_{2}+\cdots+e_{p 2} X_{p} \\
& Y_{p}=e_{p}{ }^{\prime} X=e_{1 p} X_{1}+e_{2 p} X_{2}+\cdots+e_{p p} X_{p} \\
& \text { dengan } \\
& \begin{array}{ll}
\operatorname{Var}\left(Y_{i}\right)=e_{i}{ }^{\prime} \sum e_{i} & i=1,2,3, \ldots, p \\
\operatorname{Kov}\left(Y_{i}, Y_{k}\right)=e_{i}{ }^{\prime} \sum e_{k} & i \neq k=1,2,3, \ldots, p
\end{array}
\end{aligned}
$$

Komponen utama pertama adalah kombinasi linier dengan varian maksimum, yaitu dengan memaksimumkan varian $Y_{i}=e_{i}{ }^{\prime} \Sigma e_{i}$. Hal ini dapat dilakukan dengan memberi batasan koefisien vektor mempunyai panjang satu atau $e_{i}{ }^{\prime} \Sigma e_{i}=1$. Dengan demikian dapat didefinisikan bahwa komponen utama pertama adalah kombinasi linier $e_{1}{ }^{\prime} X$ sedemikian hingga var $e_{1}{ }^{\prime} X$ maksimum bila $e_{1}{ }^{\prime} e_{1}=1$. Komponen utama kedua adalah kombinasi linier $e_{2}{ }^{\prime} X$ sedemikian hingga var $e_{2}{ }^{\prime} X$ maksimum bila $e_{2}{ }^{\prime} e_{2}=1$ dan kov $\left(e_{1}{ }^{\prime} X, e_{2}{ }^{\prime} X\right)=0$. Dan secara umum komponen utama ke-i adalah kombinasi linier $e_{i}{ }^{\prime} X$ sedemikian hingga var $e_{i}{ }^{\prime} X$ maksimum bila $e_{i}{ }^{\prime} e_{i}=1$ dan kov $\left(e_{i}{ }^{\prime} X, e_{i}{ }^{\prime} X\right)=0$ untuk $\mathrm{k} \neq \mathrm{i}$. Hal ini menunjukkan bahwa antar komponen utama tersebut saling bebas dan memiliki variasi sama dengan eigenvalue dari $\Sigma$ sehingga

$$
\sigma_{11}+\sigma_{22}+\cdots+\sigma_{p p}=\sum_{i=1}^{p} \operatorname{Var}\left(X_{i}\right)
$$

Persamaan (2.8) disebut total keragaman yang diterangkan oleh komponen utama. Koefisien korelasi antara $\mathrm{Y}_{\mathrm{i}}$ dan $\mathrm{X}_{\mathrm{k}}$ adalah:

$$
\rho_{Y_{i}, X_{k}}=\frac{\operatorname{Kov}\left(Y_{i}, X_{k}\right)}{\sqrt{\operatorname{Var}\left(Y_{i}\right)} \sqrt{\operatorname{Var}\left(X_{k i}\right)}} ; i, k=1,2, \ldots, p
$$

Apabila satuan unit pengukuran setiap variabel yang diamati berbeda, maka digunakan matriks korelasi $\mathrm{R}$ dari variabel terstandarisasi $Z$, yaitu:

$$
Z_{i}=\frac{X_{i}-\bar{X}}{S_{i}}
$$

dengan: $S_{i}=$ standart deviasi $X_{i}, \quad \bar{X}=$ mean dari $X p$ untuk $i=1,2, \ldots, p$. Maka vektor baru $Z=\left(Z_{1}, Z_{2}, \ldots, Z_{p}\right)^{\prime}$ berdistribusi multivariat normal dengan mean $\mu^{\prime}=(0,0, \ldots, 0)$.

\section{HASIL DAN PEMBAHASAN}

\subsection{Karakteristik DBD di Provinsi Maluku Utara}

Provinsi Maluku Utara merupakan salah satu provinsi yang termasuk dalam daerah dengan peningkatan cukup banyak penderita DBD di wilayah Indonesia. Dinas Kesehatan Provinsi Maluku Utara menyatakan bahwa di Provinsi Maluku Utara belum dinyatakan sebagai daerah Kejadian Luar Biasa DBD karena jumlah penderita DBD di masing-masing kabupaten/kota relatif sedikit dan belum ada yang meninggal jika dibandingkan dengan Provinsi-provinsi lain di Indonesia. 


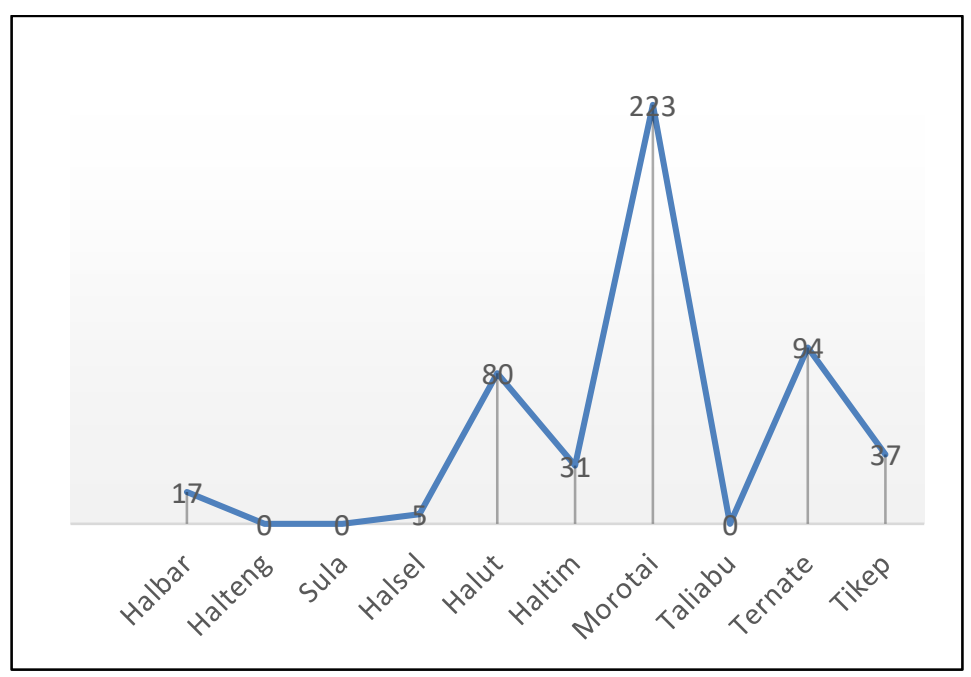

Gambar 1. Penderita DBD per Kabupaten/Kota

Berdasarkan Gambar 1 diperoleh informasi bahwa pada tahun 2018 DBD pada kabupaten/kota yang lebih banyak penderita adalah Kabupaten Pulau Morotai dengan 223 kasus diikuti Kota Ternate sebanyak 94 kasus. Sedangkan Kabupaten Halmahera Tengah dan Kabupaten Kepulauan Sula tidak didapati penderita DBD. Hal ini disebabkan karena 2 daerah tersebut tidak melaporkan data secara real time baik dari Puskesmas Pembantu, Puskesmas, maupun Rumah Sakit [5]. Untuk mencari solusi permasalahan terjadi banyaknya kasus DBD di Provinsi Maluku Utara maka salah satunya adalah mengidentifikasi faktor-faktor yang sangat signifikan berpengaruh terhadap kasus tersebut. Pada penelitian ini digunakan konsep matematika dan statistika yaitu Principal Component Analysis (PCA) untuk melihat faktor-faktor yang berpengaruh terhadap peningkatan jumlah DBD di Provinsi Maluku Utara.

\subsection{Metode Principal Component Analysis Pada Data Demam Berdarah Dengue}

Sebelum mengolah data dan dilanjutkan analisis dengan metode PCA maka langkah pertama adalah menguji keseluruhan variabel berdistribusi normal atau tidak. Dalam analisis PCA syarat kenormalan data bukanlah syarat mutlak terpenuhi, namun dengan asumsi bahwa data yang baik adalah data yang berdistribusi normal maka perlu dilakukan uji normalitas. Pengujian normalitas ini menggunakan Kolmogorov-Smirnov atau biasa disebut dengan uji K-S. Pada pengujian K-S, kriteria sebuah variabel dikatakan berdistribusi normal jika nilai signifikansi dari variabel lebih besar dari 0,05 .

Tabel 1. Uji Normalitas Variabel Penelitian

\begin{tabular}{lc}
\hline \multicolumn{1}{c}{ Variabel Penelitian } & Nilai Sig \\
\hline Penduduk Bukan Angkatan Kerja $\left(\mathrm{X}_{1}\right)$ & 0,15 \\
\hline Tenaga Medis $\left(\mathrm{X}_{2}\right)$ & 0,50 \\
\hline Penduduk usia rentan $\left(\mathrm{X}_{3}\right)$ & 0,09 \\
\hline Penduduk Angkatan Kerja $\left(\mathrm{X}_{4}\right)$ & 0,14 \\
\hline Desa dengan Sarana Kesehatan $\left(\mathrm{X}_{5}\right)$ & 0,20 \\
\hline Fasilitas Kesehatan $\left(\mathrm{X}_{6}\right)$ & 0,20 \\
\hline Rumah Tangga dengan Sanitasi Layak $\left(\mathrm{X}_{7}\right)$ & 0,20 \\
\hline
\end{tabular}

Pada Tabel 1 diperoleh semua variabel independen penduduk bukan angkatan kerja $\left(\mathrm{X}_{1}\right)$, tenaga medis $\left(\mathrm{X}_{2}\right)$, penduduk usia rentan $\left(\mathrm{X}_{3}\right)$, penduduk angkatan kerja $\left(\mathrm{X}_{4}\right)$, desa dengan sarana kesehatan $(\mathrm{X} 5)$, dan fasilitas kesehatan (X6) dan persentase rumah tangga dengan sanitasi layak (X7)berdistribusi normal karena nilai signifikansi semua variabel $>0,05$, maka keseluruhan data tersebut dapat dilanjutkan dengan analisis PCA.

Tabel 2. Hasil Uji KMO dan Bartletts

\begin{tabular}{lc}
\hline \multicolumn{1}{c}{ Uji } & Nilai Sig \\
\hline Kaiser-Meyer-Olkin Measure & 0,67 \\
\hline Bartlett's Test of Sphericity & 0,00 \\
\hline
\end{tabular}


Hasil pengujian KMO dan Bartlest test pada Tabel 2 diperoleh nilai KMO sebesar 0,67>0,5 dan nilai Bartlett's Test of Sphericity nilai signifikansi $0,00<0,05$ maka semua variabel pada penelitian ini memenuhi uji KMO dan Bartlest jadi dapat dilanjutkan pada tahap berikutnya. Berikut nilai korelasi pada uji anti image correlation harus lebih dari $0,5(>0,5)$. Selanjutnya adalah pemenuhan asumsi korelasi antar variabel independen.

Tabel 3. Uji Anti Image Correlation

\begin{tabular}{lccccccc}
\hline Variabel Penelitian & $\mathbf{X}_{\mathbf{1}}$ & $\mathbf{X}_{\mathbf{2}}$ & $\mathbf{X}_{\mathbf{3}}$ & $\mathbf{X}_{\mathbf{4}}$ & $\mathbf{X}_{\mathbf{5}}$ & $\mathbf{X}_{\mathbf{6}}$ & $\mathbf{X}_{\mathbf{7}}$ \\
\hline Penduduk bukan angkatan kerja $\left(\mathrm{X}_{1}\right)$ & $\mathbf{0 , 8 5} *$ & 0,13 & $-0,33$ & $-0,23$ & $-0,02$ & 0,18 & $-0,49$ \\
\hline Tenaga medis $\left(\mathrm{X}_{2}\right)$ & 0,13 & $\mathbf{0 , 5 2} *$ & $-0,63$ & 0,72 & $-0,44$ & $-0,76$ & $-0,34$ \\
\hline Penduduk usia rentan $\left(\mathrm{X}_{3}\right)$ & $-0,33$ & $-0,63$ & $\mathbf{0 , 7 2} *$ & $-0,74$ & 0,06 & 0,37 & 0,38 \\
\hline Penduduk angkatan kerja $\left(\mathrm{X}_{4}\right)$ & $-0,23$ & 0,72 & $-0,74$ & $\mathbf{0 , 6 3} *$ & $-0,21$ & $-0,79$ & $-0,34$ \\
\hline Desa dengan sarana kesehatan $\left(\mathrm{X}_{5}\right)$ & $-0,02$ & $-0,44$ & 0,07 & $-0,21$ & $\mathbf{0 , 8 9 *}$ & 0,19 & 0,05 \\
\hline Fasilitas kesehatan $\left(\mathrm{X}_{6}\right)$ & 0,18 & $-0,76$ &, 37 & $-0,79$ & 0,19 & $\mathbf{0 , 6 5 *}$ & 0,43 \\
\hline Persentase RT sanitasi layak $\left(\mathrm{X}_{7}\right)$ & $-0,49$ & $-0,34$ &, 38 & $-0,34$ & 0,05 & 0,43 & $\mathbf{0 , 3 8}$ \\
\hline
\end{tabular}

Pada Tabel 3 di atas diperoleh korelasi antar variabel independen sangat kuat yakni >0,5 untuk semua variabel yang diartikan bahwa semua variabel independen dapat dilakukan pengujian selanjutnya, kecuali pada persentase RT dengan sanitasi layak $\left(X_{7}\right)$. Persentase RT dengan sanitasi layak $\left(X_{7}\right)$ memiliki nilai korelasi $0,38<0,5$ sehingga variabel tersebut dikeluarkan dari data yang dianalisis. Variabel Penduduk bukan angkatan kerja $\left(\mathrm{X}_{1}\right)$, tenaga medis $\left(\mathrm{X}_{2}\right)$, penduduk usia rentan $\left(\mathrm{X}_{3}\right)$, penduduk angkatan kerja $\left(\mathrm{X}_{4}\right)$, Desa dengan sarana kesehatan $\left(\mathrm{X}_{5}\right)$, dan fasilitas kesehatan $\left(\mathrm{X}_{6}\right)$ diuji seberapa besar faktor yang terbentuk uji ini disebut dengan communalities dan juga untuk menerangkan varian suatu komponen.

Tabel 4. Uji Communalities

\begin{tabular}{lcc}
\hline \multicolumn{1}{c}{ Variabel Penelitian } & Initial & Extraction \\
\hline Penduduk bukan angkatan kerja $\left(\mathrm{X}_{1}\right)$ & 1,00 & 0,63 \\
\hline Tenaga medis $\left(\mathrm{X}_{2}\right)$ & 1,00 & 0,56 \\
\hline Penduduk usia rentan $\left(\mathrm{X}_{3}\right)$ & 1,00 & $0,94^{*}$ \\
\hline Penduduk angkatan kerja $\left(\mathrm{X}_{4}\right)$ & 1,00 & 0,89 \\
\hline Desa dengan sarana kesehatan $\left(\mathrm{X}_{5}\right)$ & 1,00 & 0,69 \\
\hline Fasilitas kesehatan $\left(\mathrm{X}_{6}\right)$ & 1,00 & 0,86 \\
\hline
\end{tabular}

Berdasarkan Tabel 4 di atas dapat dilihat bahwa pada kolom initial nilai communalities untuk setiap variabel adalah 1,00 dan pada kolom extraction menunjukkan seberapa besar faktor yang terbentuk dapat menerangkan varian suatu variabel. Dapat dilihat nilai communalities tertinggi pada variabel penduduk usia rentan $\left(X_{3}\right)$ yang artinya variabel penduduk usia rentan dapat menjelaskan $94 \%$ varians faktor yang terbentuk. Sedangkan nilai communalities terendah pada variabel jumlah tenaga medis $\left(\mathrm{X}_{2}\right)$ sebesar 0,56 yang artinya variabel jumlah tenaga medis dapat mampu menjelaskan $56 \%$ varians faktor yang terbentuk. Semua variabel dapat dijelaskan dengan melihat nilai communalities pada kolom extraction dengan ketentuan jika semakin besar nilai communalities maka semakin kuat hubungan variabel yag bersangkutan dengan faktor yang terbentuk. Selanjutnya menganalisis banyak faktor yang terbentuk dengan melihat output total varians. Output total varians yang dapat menjelaskan secara deskriptif berapa faktor yang terbentuk dari ke-enam variabel yang dianalisis dalam penelitian ini.

Tabel 5. Output Total Varians Explained

\begin{tabular}{ccccccc}
\hline & \multicolumn{3}{c}{ Initial Eigenvalues } & \multicolumn{2}{c}{ Extraction Sums of Loadings } \\
\cline { 2 - 7 } Component & Total & Variance & Cumulative & Total & Variance & Cumulative \\
\hline $\mathrm{X}_{1}$ & 4,58 & 76,38 & 76,38 & 4,58 & 76,38 & 76,38 \\
\hline $\mathrm{X}_{2}$ & 0,91 & 15,16 & 91,54 & & & \\
\hline $\mathrm{X}_{3}$ & 0,32 & 5,30 & 96,84 & & & \\
\hline $\mathrm{X}_{4}$ & 0,13 & 2,19 & 99,03 & & \\
\hline $\mathrm{X}_{5}$ & 0,05 & 0,76 & 99,79 & & \\
\hline $\mathrm{X}_{6}$ & 0,01 & 0,21 & 100 & & \\
\hline
\end{tabular}


Berdasarkan Tabel 5 dapat dilihat bahwa dari ke-enam komponen masing-masing dengan initial eigenvalues total yakni 4,$58 ; 0,91 ;, 0,32 ;, 0,13 ;, 0,05 ;$, dan 0,01 . Total varians dari semua komponen adalah $76,38 \%, 15,16 \%, 5,30 \%, 2,19 \%, 0,76 \%$ dan $0,21 \%$. Kumulatif dari total varians semua komponen adalah 100. Untuk mengetahui apakah semua variabel itu membentuk berapa faktor dapat dilihat pada extraction sums of squared loadings dengan nilai total 4,58. Pada tabel terlihat bahwa nilai ekstraksi hanya terdiri dari 1 saja $(4,58)$ maka semua variabel membentuk 1 faktor dengan total varians $76,38 \%$ dan kumulatif total varians juga sama $76,38 \%$. Untuk melihat dengan jelas apakah semua variabel pada penelitian ini membentuk 1 faktor, maka bisa digunakan scree plot. Pada Gambar 2 diketahui bahwa scree plot mulai mendatar pada ekstraksi variabel-variabel awal menjadi 1 faktor.

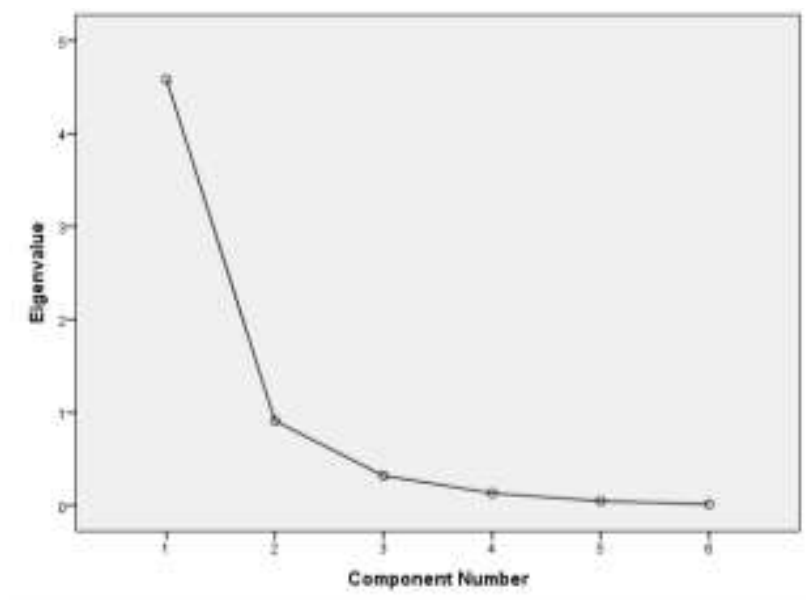

Gambar 2. Scree Plot

Berdasarkan hasil communalities, total varians dan scree plot dapat disimpulkan bahwa hanya satu kelompok dengan faktor yang telah terbentuk pada determinan DBD di Provinsi Maluku Utara. Setelah diperoleh hasil pembentukan faktor maka selanjutnya adalah melihat nilai hasil komponen matriks dengan PCA untuk dapat menginterpretasi sekaligus mengambil kesimpulan dari penelitian ini.

Tabel 6. Output Component Matrix

\begin{tabular}{lc}
\hline \multirow{2}{*}{ Variabel Penelitian } & Component \\
\cline { 2 - 2 } & $\mathbf{1}$ \\
\hline Penduduk bukan angkatan kerja $\left(\mathrm{X}_{1}\right)$ & 0,79 \\
\hline Tenaga medis $\left(\mathrm{X}_{2}\right)$ & 0,75 \\
\hline Penduduk usia rentan $\left(\mathrm{X}_{3}\right)$ & 0,97 \\
\hline Penduduk angkatan kerja $\left(\mathrm{X}_{4}\right)$ & 0,95 \\
\hline Desa dengan sarana kesehatan $\left(\mathrm{X}_{5}\right)$ & 0,83 \\
\hline Fasilitas kesehatan $\left(\mathrm{X}_{6}\right)$ & 0,93 \\
\hline
\end{tabular}

Berdasarkan Tabel 6 dapat dilihat bahwa untuk semua variabel penduduk bukan angkatan kerja $\left(\mathrm{X}_{1}\right)$, tenaga medis $\left(\mathrm{X}_{2}\right)$, penduduk usia rentan $\left(\mathrm{X}_{3}\right)$, penduduk angkatan kerja $\left(\mathrm{X}_{4}\right)$, Desa dengan sarana kesehatan $\left(\mathrm{X}_{5}\right)$, dan fasilitas kesehatan $\left(\mathrm{X}_{6}\right)$ semua termasuk dalam faktor komponen 1. Menurut kriteria secara statistik hasil ekstraksi 1 faktor dikatakan akurat jika variabel yang diambil kurang dari 30 variabel, pada penelitian ini hanya terdapat 6 variabel sehingga memenehui kriteria. Dengan demikian 6 variabel diatas dengan 1 faktor tersebut bernilai akurat yang artinya semua variabel penduduk bukan angkatan kerja $\left(\mathrm{X}_{1}\right)$, tenaga medis $\left(\mathrm{X}_{2}\right)$, penduduk usia rentan $\left(\mathrm{X}_{3}\right)$, penduduk angkatan kerja $\left(\mathrm{X}_{4}\right)$, desa dengan sarana kesehatan $\left(\mathrm{X}_{5}\right)$, dan fasilitas kesehatan $\left(\mathrm{X}_{6}\right)$.

\section{KESIMPULAN}

Pada analisis PCA jumlah keseluruhan variabel adalah 6 variabel setelah data persentase rumah tangga dengan sanitasi layak $\left(\mathrm{X}_{7}\right)$ dieliminasi. Hasil penelitian diperoleh semua variabel independen membentuk 1 faktor atau 1 komponen. 


\section{DAFTAR PUSTAKA}

[1] [WHO] World Health Organization. "Dengue Guidelines for Diagnosis, Treatment, Prevention and Control". WHO. Geneva , 2009

[2] Dinkes Provinsi Maluku Utara. "Laporan Kesehatan Provinsi Maluku Utara". Ternate, 2019

[3] Depkes RI. "Data Kasus DBD per Bulan di Indonesia Tahun 2010, 2009 dan 2008". Jakarta: Depkes RI, 2010

[4] Noya V.D. "Penggunaan Analisis Komponen Utama Pada Data Inflasi Kota Ambon". BAREKENG: Jurnal Ilmu Matematika dan Terapan, 109-118, 2017

[5] Dinkes Provinsi Maluku Utara. "Publikasi Kesehatan Provinsi Maluku Utara". Ternate, 2019

[6] Johnson, R.A and Wichern, D.W. "Applied Multivariate Statistical Analysis". Prentice Hall, New Jersey,2020

[7] Suryanto. "Metode Statistika Multivariat". Jakarta: Departemen Pendidikan dan Kebudayaan, 1988.

[8] Bilson \& Simamora. "Analisis Multivariat Pemasaran". Jakarta: Gramedia Pustaka Utama, 2005

[9] Anhara, "Analisis Faktor-Faktor Yang Mempengaruhi Manajemen Laba (Studi Pada Perusahaan Perbankan Syariah di Indonesia). Jurnal Tekun, Vol.VI, No. 01, 128-150, 2015

[10] Supranto, "Analisis Multivariat Arti dan Interpretasi". Jakarta: Rineka Cipta, 2004

[11] Ghozali dan Imam, "Aplikasi Analisis Multivariate Dengan Program SPSS". Cetakan IV. Semarang: Badan Penerbit Universitas Diponegoro, 2006

[12] Kotler, "Manajemen Pemasaran Edisi Miilenium Satu". Jakarta: Prenhallindo, 2002

[13] Iriawan, N \& Astuti, S.P.. Mengolah Data Statistik dengan Mudah Menggunakan Minitab 14. Yogyakarta: ANDI, 2006

[14] Suryanto. Metode Statistika Multivariat. Jakarta: Departemen Pendidikan dan Kebudayaan, 1988.

[15] Yusralaini et.al. "Analisis Faktor-Faktor yang Mempengaruhi Ketepatan Waktu Penyampaian Laporan Keuangan Ke Publik", Jurnal Ekonomi Volume 18, 2010

[16] [WHO] World Health Organization. "Comprehensive guidelines for prevention and control of dengue and dengue hemorrhagic fever". Regional Office for South-East Asia, 2011 
